Research Journal of Biological Sciences 5 (9): 601-605, 2010

ISSN: $1815-8846$

(C) Medwell Journals, 2010

\title{
Land Suitability Analysis for Wheat Using Multicriteria Evalution and GIS Method
}

\author{
Shahram Ashraf \\ Department of Soil Science, Damghan Branch, Islamic Azad University, Damghan, Iran
}

\begin{abstract}
The aim in integrating multi-criteria evaluation with Geographical Information Systems (GIS) is to provide more flexible and more accurate decisions to the decision makers in order to valuate the effective factors. A GIS has been used to match the suitability for wheat crop based on the requirements of the crop and the quality and characteristics of land. The methodology used for the physical land suitability analysis for wheat is a multi-criteria evaluation approach within GIS context. This study, land suitability evaluation based on FAO has been determined for wheat irrigated area about 5400 ha, the South of plains Damghan. The study was carried out by overlapping all individual maps (soil map units, soil depth map, slope map, texture soil map and soil fertility) with GIS techniques for physical land suitability classification. The results show that $21.94 \%$ of the area is moderately suitable (S3) and 9.40 not suitable (N1) and $68.66 \%$ severe limitations and unchangeable (N2) for wheat crop. Lack of irrigation suitable water, Exchange Sodium Percent (ESP) and salinity (EC), insufficient rainfall and poor soil fertility are the most serious problems influencing yield and quality of wheat.
\end{abstract}

Key words: Land suitability, wheat, climate, soil, GIS, multicriteria evalution

\section{INTRODUCTION}

Land suitability is the fitness of a given type of land for a defined use. The land may be considered in its present condition or after improvements. The process of land suitability classification is the appraisal and grouping of specific areas of land in terms of their suitability for defined uses. The advent of modern GIS and remote sensing technologies opened the door to the wide application of quantitative and qualitative evaluation methods. Land can be evaluated on different levels from the fine one to guide land management in the context of precision agriculture to the more course classifications to inform regional land use planning and allocation (Franzen et al., 2006). Recently methodologies are being developed to facilitate and streamline the process of evaluation (Van Lanen et al., 1992; Ghaffari et al., 2000). These methodologies should be based on sound ecological principles and also take into account the availability of data.

They should preferably be underpinned be generally accepted framework and yet be flexible enough to accommodate for local differences on ecological, environmental and social conditions. Thus instead of collecting large amounts of ground data, efforts should prioritize on the search for the ways to utilize the available data. It is apparent that the accomplishment of almost any project aimed at land resources planning may be greatly facilitated by the use of and efficient GIS (Dragan et al., 2003). The main aim of this study was to identify, the suitable land parcels for a production wheat in the Damghan plain. The objectives include identification of suitability criteria for a production wheat and compilation of the information in GIS for further analysis.

\section{MATERIALS AND METHODS}

Study area: The study area chosen is Damghan plain in Iran at approximately $54^{\circ} 21^{\prime} 56.73^{\prime \prime} \mathrm{E}, 54^{\circ} 27^{\prime} 24.13^{\prime \prime} \mathrm{E}$, $36^{\circ} 02^{\prime} 31.63^{\prime \prime}$ and $36^{\circ} 08^{\prime} 28.53^{\prime \prime} \mathrm{N}$ and covers an area of 5400 ha. Base map is selected from topographic map with $1: 50,000$ scale. It falls in drought-prone region of Semnan, Iran. The Damghan is located in desert margins and plant has some difficulties. The study area soils are new alluvial sediments in the 4th period of geology and parent material in the Northern and Western of plain are sediments mixed with sand and gravel. Figure 1 shows schema of the Damghan plain in Iran map.

Methodology: The methodology used for the physical land suitability analysis is a multi-criteria evaluation based on FAO land evaluation framework (FAO, 1976, 1985). The methodology consists on matching soil/land qualities against wheat needs and assigning a suitability rating to each land characteristic. In order to develop, a set of themes for evaluation and ultimately to produce a 


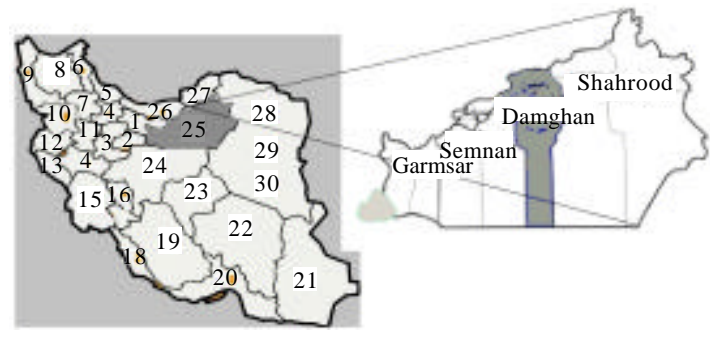

Fig. 1: The schema of the evaluation of the study area

Table 1: Determine classes of land suitability for FAO methods

\begin{tabular}{lll}
\hline Order & Class & Description \\
\hline Suitable & S1: (Highly suitable) & Land having not insignificant limitations \\
(S) & S2: (Moderately suitable) & Land having minor limitations \\
& S3: (Marginally suitable) & Land having moderate limitations \\
Suitable & N1: (Permanently & Land that have so severe limitations that \\
(N) & $\quad$ unsuitable) & are very not suitable (N) difficult to be \\
& & overcome \\
& N2: (Permanently & Land that have so severe limitations \\
& unsuitable) & that are very difficult to be overcome \\
\hline
\end{tabular}

suitability map for Damghan Plain, the crop requirement in terms of land qualities was reviewed (Sys et al., 1993). Determine classes of land suitability for a plant based fitness indicators obtained from the Table 1. Classes are divided into subclasses which indicate the nature of the limitations that make the land less than completely suitable. The subclass code contains a suffix which indicates the nature of the limitations, e.g., S3w-subclass of land marginally uitable (S3) because of the excessive wetness.

The divisions of subclasses are suitability units which while having the same degree and general kind of limitation have different anagement requirements. The actual classification is made by mapping and analyzing a set of diagnostic land characteristics that pertain to appropriate land qualities. The actual classification is made by mapping and analyzing a set of diagnostic land characteristics that pertain to appropriate land qualities. A set of data was selected and preprocessed to characterize spatially these land qualities. Detail scale $(1: 50,000)$ topographical maps for study area were digitized and interpolated in Arc GIS to produce correct Digital Elevation Models (DEM). Basic concepts in land suitability assessment in Multi Criteria Evaluation (MCE) has expressed by four steps following (Malczewski, 1999):

Factors: Factor is a general category of information concerning the site being evaluated. The factors often considered in land suitability studies include natural environment factors (slope, soil type, geologic hazards present, land cover, etc.).
Rating: Rating is an evaluation usually expressed in numerical terms of how suitable a site is supporting a specific land use. Numeric scores to a total of ten (one as least and ten as most suitable) are assigned to each factor attribute class (classification of factor attribute classes used in assessing site suitability for residential land application).

Comparisons between classes were based on their level of suitability with respect to residential land use. Since, environment factors for each specific study areas are different with others, there is no uniform standard for rating factors. In parametric approach, the researchers always rated the factors based on the situation of study area, review of literatures and suggestion from experts (Table 2).

Weight: Weighting in suitability analysis refers to assigning a numeric value to each factor in order to recognize its relative importance and usually expresses in percent format (Pease et al., 1996). A set of weights are usually used to represent the relative importance of parameters and normalized to a constant as; the weight value for the suitability of one factor used in this research was based on interpretation of published materials as well as several experts. Table 3 shows values of rating and weight for each influencing factor on wheat growth.

Score: Score is the numerical total of the calculated land suitability when the ratings and weights for all factors are considered. As described by Eastman and Labs (1999) and Pereira and Duckstein (1993), each thematic layer represented an evaluation criterion and grid cells were valued according to their quality for a particular land use. The first step, initially suitability class value and weight are assigned to individual land characteristic and then calculated the suitability score. The score for an individual site is used as a basis for comparing its suitability with other sites.

The information collection includes the data collection, literature information collection and expert knowledge collection. Based on the classification of suitability each factor has been divided into five classes from highly suitable to permanently not suitable. On the other hand, the available data are gathered together for transformed into digital format. The weight and value of factors should be identified 1st for calculating the suitability score for each land unit. The suitability map presents, the result of the construction land suitability assessment in terms of the land unit suitability scores. In this study, land suitability assessment is done by the following equation:

$$
S=\sum_{j i W j i X j i}
$$




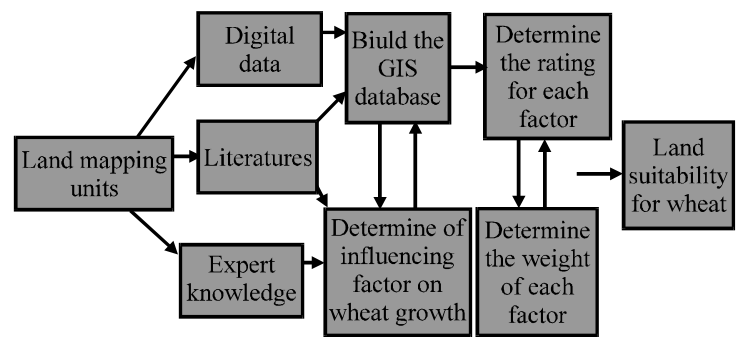

Fig. 2: Process of land suitability evaluation in this study

$\mathrm{S}=$ Suitability index (score)

wi $=$ Weight of criterion $\mathrm{i}$

$\mathrm{Ri}=$ Rating of criterion $\mathrm{i}$

Figure 2 shows process of land suitability evaluation in this study.

\section{RESULTS}

With regarding to results obtained from description of soil profiles and physical and chemical analysis of soil samples (Table 3 and 4) soils were classified as Entisols and Aridisols on the basis of soil taxonomy system 2006. In study area, two order, three family, nine soil series and two physiogrphy were identified (Table 5). The cycle of wheat growth in study area is shown in Table 6. Table 6 shows that wheat growth cycle in Damghan plain starts from 1 Nov to 21 Jun. Table 7 shows the qualitative land suitability results for wheat plant. Table 7 shows the range of classes in different land units according to Multicriteria Evaluation and GIS method that are $\mathrm{S}_{3}-\mathrm{N}_{2}$. Evaluating the land suitability using Multicriteria evaluation and GIS method indicated that two units of separated units were marginal suitable $\left(\mathrm{S}_{3}\right)$ and 1 unit was

Table 2: The determine of rating and weight for each factor

\begin{tabular}{lllllll}
\hline Ceriteria & Lime & Gypsum & Fertility $(\mathrm{pH})$ & EC (Salinity) & ESP (Alkalinity) & Rainfall \\
Weight & 0.118 & 0.01 & 0.06 & 0.33 & 0.12 & 0.13 \\
Rating & $1.5,7,9$ & $1.5,7,9$ & $1.5,7,9$ & $1.5,7,9$ & 0.03 & $1.5,7,9$ \\
Ceriteria & Slop & Dranage & Soil physics & Surface stoniness & Gravel & $1.5,7,9$ \\
\hline Weight & 0.002 & 0.04 & 0.1 & 0.02 & 0.02 & Soil depth \\
Rating & $1.5,7,9$ & $1.5,7,9$ & $1.5,7,9$ & $1.5,7,9$ & $1.5,7,9$ & 0.02 \\
\hline
\end{tabular}

Table 3: Some physico-chemical properties of representative pedons

\begin{tabular}{|c|c|c|c|c|c|c|c|c|c|c|c|}
\hline Pedons & Depth $(\mathrm{cm})$ & Sand & Silt & Clay & $\mathrm{Sp}$ & $\mathrm{Ec}$ & $\mathrm{pH}$ & $\mathrm{C}(\%)$ & $\mathrm{CaCO}_{3}$ & $\mathrm{CaSO}_{4}$ & Esp \\
\hline $\mathrm{Ap}$ & $0-30$ & 70.00 & 25.00 & 5.00 & 22 & 8.0 & 7.70 & 0.30 & 20.00 & 0.0 & 16.0 \\
\hline $\mathrm{C} 1$ & $30-65$ & 58.00 & 32.00 & 10.00 & 28 & 7.0 & 7.90 & 0.40 & 22.00 & 0.0 & 18.0 \\
\hline $\mathrm{C} 2$ & $65-95$ & 56.00 & 30.00 & 14.00 & 33 & 9.5 & 7.55 & 0.05 & 21.00 & 0.0 & 13.0 \\
\hline $\mathrm{C} 3$ & $95-130$ & 50.00 & 25.00 & 25.00 & 34 & 9.0 & 8.00 & 0.03 & 18.00 & 0.0 & 17.0 \\
\hline Ap & $0-20$ & 58.00 & 30.00 & 14.00 & 19 & 10.0 & 7.71 & 0.45 & 14.70 & 5.0 & 9.0 \\
\hline $\mathrm{C} 1$ & $20-58$ & 52.80 & 29.60 & 17.60 & 25 & 8.0 & 7.50 & 0.30 & 16.00 & 3.0 & 10.0 \\
\hline $\mathrm{C} 2$ & $58-95$ & 53.00 & 28.00 & 19.00 & 27 & 8.5 & 7.55 & 0.10 & 14.50 & 0.0 & 12.0 \\
\hline C3 & $95-130$ & 56.00 & 30.00 & 14.00 & 32 & 7.0 & 7.60 & 0.10 & 13.00 & 0.0 & 15.0 \\
\hline Ap & $0-25$ & 60.00 & 26.00 & 14.00 & 27 & 19.0 & 8.10 & 0.40 & 25.00 & 2.0 & 20.0 \\
\hline $\mathrm{C} 1$ & $25-60$ & 58.00 & 34.00 & 8.00 & 32 & 15.0 & 8.15 & 0.03 & 29.00 & 0.0 & 23.0 \\
\hline $\mathrm{C} 2$ & $60-95$ & 56.00 & 30.00 & 14.00 & 34 & 18.0 & 7.75 & 0.02 & 33.00 & 0.0 & 30.0 \\
\hline C3 & $95-150$ & 52.00 & 36.00 & 12.00 & 34 & 20.0 & 7.75 & 0.02 & 33.00 & 0.0 & 35.0 \\
\hline A1 & $0-30$ & 45.00 & 35.00 & 20.00 & 27 & 15.0 & 8.00 & 0.22 & 34.70 & 11.0 & 25.0 \\
\hline $\mathrm{C} 1$ & $30-60$ & 22.00 & 37.00 & 41.00 & 44 & 18.0 & 8.10 & 0.23 & 36.20 & 0.0 & 35.0 \\
\hline $\mathrm{C} 2$ & $60-85$ & 32.00 & 32.00 & 36.00 & 52 & 24.0 & 8.20 & 0.18 & 31.50 & 0.0 & 30.0 \\
\hline C3 & $85-120$ & 30.00 & 33.00 & 37.00 & 41 & 15.0 & 8.10 & 0.22 & 32.00 & 0.0 & 25.0 \\
\hline Ap & $0-25$ & 52.00 & 36.00 & 12.00 & 23 & 20.0 & 7.50 & 0.50 & 30.45 & 6.0 & 25.0 \\
\hline $\mathrm{C} 1$ & $25-60$ & 46.80 & 24.60 & 28.60 & 28 & 16.0 & 8.44 & 0.08 & 28.00 & 0.0 & 28.0 \\
\hline $\mathrm{C} 2$ & $60-95$ & 48.00 & 27.60 & 27.60 & 27 & 8.0 & 8.75 & 0.05 & 31.50 & 0.0 & 23.0 \\
\hline $\mathrm{C} 3$ & $95-125$ & 23.27 & 45.43 & 31.30 & 30 & 10.0 & 8.50 & 0.05 & 33.00 & 0.0 & 29.0 \\
\hline Ap & $0-25$ & 67.40 & 28.59 & 4.05 & 19 & 9.0 & 7.60 & 0.30 & 18.00 & 2.0 & 13.0 \\
\hline $\mathrm{C} 1$ & $25-60$ & 53.00 & 25.30 & 21.70 & 30 & 10.0 & 7.90 & 0.15 & 20.00 & 0.0 & 15.0 \\
\hline $\mathrm{C} 2$ & $60-95$ & 51.00 & 24.00 & 25.00 & 32 & 12.0 & 8.10 & 0.15 & 19.00 & 0.0 & 18.0 \\
\hline C3 & $95-125$ & 55.50 & 21.00 & 23.50 & 33 & 14.0 & 8.20 & 0.13 & 20.00 & 0.0 & 16.5 \\
\hline A1 & $0-20$ & 45.00 & 35.00 & 20.00 & 40 & 111.0 & 7.70 & 0.50 & 32.50 & 9.8 & 50.0 \\
\hline B & $20-60$ & 35.00 & 30.00 & 35.00 & 31 & 110.0 & 8.10 & 0.09 & 27.00 & 6.8 & 56.4 \\
\hline $\mathrm{C} 2$ & $60-100$ & 36.00 & 29.00 & 35.00 & 30 & 113.0 & 8.20 & 0.04 & 38.50 & 14.0 & 28.5 \\
\hline C3 & $100-160$ & 25.00 & 37.00 & 38.00 & 27 & 116.0 & 8.30 & 0.07 & 38.20 & 16.0 & 34.6 \\
\hline $\mathrm{A} 1$ & $0-25$ & 51.00 & 25.50 & 23.50 & 40 & 100.0 & 7.70 & 0.30 & 32.50 & 8.0 & 47.0 \\
\hline $\mathrm{C} 1$ & $25-65$ & 20.00 & 45.00 & 35.00 & 31 & 98.0 & 7.90 & 0.09 & 27.00 & 6.0 & 38.0 \\
\hline $\mathrm{C} 2$ & $65-95$ & 36.00 & 30.00 & 34.00 & 30 & 80.0 & 8.00 & 0.04 & 38.50 & 10.0 & 45.0 \\
\hline C3 & $95-150$ & 25.00 & 37.00 & 38.00 & 27 & 120.0 & 8.10 & 0.07 & 38.00 & 14.0 & 49.0 \\
\hline A1 & $0-20$ & 44.00 & 36.00 & 20.00 & 25 & 40.0 & 8.18 & 0.35 & 31.00 & 4.0 & 40.0 \\
\hline $\mathrm{C} 1$ & $20-65$ & 45.00 & 27.00 & 28.00 & 30 & 25.0 & 7.70 & 0.08 & 28.00 & 2.0 & 38.0 \\
\hline $\mathrm{C} 2$ & $65-95$ & 35.00 & 28.50 & 36.50 & 28 & 60.0 & 7.80 & 0.05 & 34.00 & 0.0 & 40.0 \\
\hline C3 & $95-155$ & 16.40 & 58.40 & 25.20 & 24 & 50.0 & 8.10 & 0.00 & 35.00 & 0.0 & 42.0 \\
\hline
\end{tabular}


Res. J. Biol. Sci., 5 (9): 601-605, 2010

Table 4:Morphological characteristics of representative pedons

\begin{tabular}{|c|c|c|c|c|c|c|c|c|c|}
\hline Pedons & Depth (cm) & Color (dry) & Color (moist) & Texture & Structure & Boundry & Consistence dry & Consistence wet & $\mathrm{HCl}$ reaction \\
\hline Ap & $0-30$ & $5 \mathrm{YR} 3 / 4$ & $5 Y R 4 / 4$ & SL & 1fabk-ma & gw & sh & $\mathrm{ss} / \mathrm{ps}$ & esf \\
\hline $\mathrm{C} 1$ & $30-65$ & $10 \mathrm{YR} 7 / 2$ & 10 YR $5 / 3$ & SL & ma & gw & $\mathrm{h}$ & $\mathrm{ss} / \mathrm{ps}$ & esc \\
\hline $\mathrm{C} 2$ & $65-95$ & $10 \mathrm{YR} 7 / 2$ & $10 \mathrm{YR} 5 / 4$ & $\mathrm{SL}$ & $\mathrm{ma}$ & gw & $\mathrm{h}$ & $\mathrm{s} / \mathrm{p}$ & esc \\
\hline $\mathrm{C} 3$ & $95-130$ & $10 \mathrm{YR} 7 / 2$ & $10 \mathrm{YR} 5 / 4$ & SCL & ma & & $\mathrm{h}$ & $\mathrm{s} / \mathrm{p}$ & esm \\
\hline Ap & $0-20$ & $5 \mathrm{YR} 3 / 4$ & $5 Y R 4 / 4$ & SL & 1fabk-ma & gw & sh & $\mathrm{ss} / \mathrm{ps}$ & esf \\
\hline $\mathrm{C} 1$ & $20-58$ & $5 \mathrm{YR} 3 / 4$ & $5 Y R 4 / 4$ & SL & ma & gw & sh & $\mathrm{ss} / \mathrm{ps}$ & esf \\
\hline $\mathrm{C} 2$ & $58-95$ & 5 YR $5 / 4$ & $5 Y R 4 / 4$ & $\mathrm{~L}$ & $\mathrm{ma}$ & gw & $\mathrm{h}$ & $\mathrm{s} / \mathrm{p}$ & esf \\
\hline $\mathrm{C} 3$ & $95-130$ & $5 \mathrm{YR} 4 / 4$ & 5YR5/4 & $\mathrm{L}$ & $\mathrm{ma}$ & & $\mathrm{h}$ & $\mathrm{s} / \mathrm{p}$ & esf \\
\hline Ap & $0-25$ & 10YR6/2 & 10 YR $5 / 3$ & $\mathrm{SL}$ & 1fabk-ma & gw & sh & ss/po & esm \\
\hline $\mathrm{C} 1$ & $25-60$ & $10 \mathrm{YR} 7 / 2$ & 10YR $5 / 3$ & SL & $\mathrm{ma}$ & gw & sh & $\mathrm{ss} / \mathrm{ps}$ & esm \\
\hline $\mathrm{C} 2$ & $60-95$ & $10 \mathrm{YR} 7 / 3$ & 10 YR $5 / 3$ & SL & $\mathrm{ma}$ & gw & $\mathrm{h}$ & $\mathrm{ss} / \mathrm{ps}$ & esm \\
\hline $\mathrm{C} 3$ & $95-150$ & $10 \mathrm{YR} 7 / 2$ & 10 YR $5 / 4$ & SL & $\mathrm{ma}$ & & $\mathrm{h}$ & $\mathrm{ss} / \mathrm{ps}$ & esm \\
\hline A1 & $0-30$ & $10 \mathrm{YR} 5 / 4$ & $10 \mathrm{YR} 4 / 4$ & $\mathrm{~L}$ & $\mathrm{ma}$ & gw & $\mathrm{h}$ & $\mathrm{s} / \mathrm{p}$ & esm \\
\hline $\mathrm{C} 1$ & $30-60$ & $10 \mathrm{YR} 5 / 4$ & $10 \mathrm{YR} 4 / 4$ & $\mathrm{CL}$ & ma & gw & vh & $\mathrm{s} / \mathrm{p}$ & esm \\
\hline $\mathrm{C} 2$ & $60-85$ & $10 \mathrm{YR} 5 / 54$ & $10 \mathrm{YR} 4 / 4$ & $\mathrm{CL}$ & $\mathrm{ma}$ & gw & vh & $\mathrm{s} / \mathrm{p}$ & esm \\
\hline $\mathrm{C} 3$ & $85-120$ & 10YR5/4 & $10 \mathrm{YR} 4 / 4$ & $\mathrm{CL}$ & ma & & vh & $\mathrm{s} / \mathrm{p}$ & esm \\
\hline Ap & $0-25$ & 10YR6/3 & $10 \mathrm{YR} 4 / 3$ & SL & 1fabk-ma & gw & $\mathrm{h}$ & ss/po & esm \\
\hline $\mathrm{C} 1$ & $25-60$ & 10YR6/3 & $10 \mathrm{YR} 4 / 3$ & SCL & ma & gs & $\mathrm{h}$ & $\mathrm{s} / \mathrm{p}$ & esm \\
\hline $\mathrm{C} 2$ & $60-95$ & 10YR6/3 & $10 \mathrm{YR} 5 / 3$ & SCL & $\mathrm{ma}$ & gs & $\mathrm{h}$ & $\mathrm{s} / \mathrm{p}$ & esm \\
\hline $\mathrm{C} 3$ & $95-125$ & $10 \mathrm{YR} 7 / 3$ & 10YR5/3 & CL & $\mathrm{ma}$ & & $\mathrm{h}$ & $\mathrm{s} / \mathrm{p}$ & esm \\
\hline Ap & $0-25$ & 10YR6/3 & $10 \mathrm{YR} 4 / 3$ & SL & 1fabk-ma & gw & sh & ss/po & esf \\
\hline $\mathrm{C} 1$ & $25-60$ & $10 \mathrm{YR} 7 / 2$ & $10 \mathrm{YR} 5 / 3$ & SCL & $\mathrm{ma}$ & gw & $\mathrm{h}$ & $\mathrm{s} / \mathrm{p}$ & esc \\
\hline $\mathrm{C} 2$ & $60-95$ & $10 \mathrm{YR} 6 / 2$ & $10 \mathrm{YR} 5 / 3$ & SCL & ma & gw & $\mathrm{h}$ & $\mathrm{s} / \mathrm{p}$ & esf \\
\hline $\mathrm{C} 3$ & $95-125$ & $10 \mathrm{YR} 7 / 3$ & $10 \mathrm{YR} 5 / 3$ & SCL & $\mathrm{ma}$ & & $\mathrm{h}$ & $\mathrm{s} / \mathrm{p}$ & esc \\
\hline A1 & $0-20$ & 10RY5/4 & $10 \mathrm{YR} 4 / 4$ & $\mathrm{~L}$ & $\mathrm{ma}$ & gw & $\mathrm{h}$ & $\mathrm{ss} / \mathrm{ps}$ & esm \\
\hline $\mathrm{C} 1$ & $20-60$ & $7.5 R Y 5 / 4$ & $7.5 \mathrm{YR} 4 / 4$ & $\mathrm{CL}$ & $\mathrm{ma}$ & gw & wh & $\mathrm{s} / \mathrm{p}$ & esm \\
\hline $\mathrm{C} 2$ & $60-100$ & $7.5 \mathrm{YR} 4 / 4$ & $7.5 \mathrm{YR} 4 / 4$ & $\mathrm{CL}$ & $\mathrm{ma}$ & gw & $\mathrm{h}$ & $\mathrm{s} / \mathrm{p}$ & esm \\
\hline C3 & $100-160$ & $7.5 \mathrm{YR} 4 / 4$ & $7.5 \mathrm{YR} 4 / 4$ & CL & $\mathrm{ma}$ & & $\mathrm{h}$ & $\mathrm{s} / \mathrm{p}$ & esm \\
\hline A1 & $0-25$ & 10RY5/4 & $10 \mathrm{YR} 4 / 4$ & SCL & ma & gw & $\mathrm{h}$ & $\mathrm{ss} / \mathrm{ps}$ & esm \\
\hline $\mathrm{C} 1$ & $25-65$ & $7.5 \mathrm{RY} 5 / 4$ & $10 \mathrm{YR} 4 / 4$ & CL & $\mathrm{ma}$ & gw & vh & $\mathrm{s} / \mathrm{p}$ & esm \\
\hline $\mathrm{C} 2$ & $65-95$ & $7.5 \mathrm{YR} 4 / 4$ & $10 \mathrm{YR} 4 / 4$ & $\mathrm{CL}$ & $\mathrm{ma}$ & gw & vh & $\mathrm{s} / \mathrm{p}$ & esm \\
\hline $\mathrm{C} 3$ & $95-150$ & $7.5 \mathrm{YR} 5 / 4$ & 7.5YR $4 / 4$ & $\mathrm{CL}$ & $\mathrm{ma}$ & & vh & $\mathrm{s} / \mathrm{p}$ & esm \\
\hline A1 & $0-20$ & 10RY5/4 & $10 \mathrm{YR} 4 / 4$ & $\mathrm{~L}$ & $\mathrm{ma}$ & gw & $\mathrm{h}$ & $\mathrm{s} / \mathrm{p}$ & esm \\
\hline $\mathrm{C} 1$ & $20-65$ & 10RY6/4 & 10YR4/4 & SCL & ma & $\mathrm{g}$ & vh & $\mathrm{s} / \mathrm{p}$ & esm \\
\hline $\mathrm{C} 2$ & $65-95$ & 10RY5/4 & $10 \mathrm{YR} 4 / 4$ & $\mathrm{CL}$ & ma & gs & vh & $\mathrm{s} / \mathrm{p}$ & esm \\
\hline C3 & $95-155$ & 7.5 YR $4 / 4$ & $7.5 \mathrm{YR} 4 / 4$ & $\mathrm{CL}$ & ma & & vh & $\mathrm{s} / \mathrm{p}$ & esm \\
\hline
\end{tabular}

Table 5: Soil classifiation of study region

\begin{tabular}{lcl} 
Physiography & land units & Taxonomy USDA soil \\
\hline Alluvium plain & 1.1 & Coarse loamy, mixed, thermic Typic Torrifluents Entisols \\
Alluvium plain & 1.2 & Coarse loamy, mixed, thermic Typic Torrifluents Entisols \\
Alluvium plain & 1.3 & Coarse loamy, mixed, thermic Typic Torrifluents Entisols \\
Alluvium plain & 2.1 & Fine loamy, mixed, thermic Typic Torriorthents Entisols \\
Alluvium plain & 2.2 & Fine loamy, mixed, thermic Typic Torriorthents Entisols \\
Alluvium plain & 2.3 & Fine loamy, mixed, thermic Typic Torriorthents Entisols \\
Low land & 3.1 & Fine loamy, mixed, thermic Typic Aquisalids Aridisols \\
Low land & 3.2 & Fine loamy, mixed, thermic Typic Aquisalids Aridisols \\
Low land & 3.3 & Fine loamy, mixed, thermic Typic Aquisalids Aridisols \\
\hline
\end{tabular}

Table 6: Study of wheat growth cycle in the region

\begin{tabular}{lllllll}
\hline Plant & Planting to stability & Vegetative stage & Flowering stage & Ripening stage & Harvest & Growing cycle \\
\hline Wheat & 1 November to 21 November & 21 November to 10 April & 10 April to10 May & 10 May to 21 June & 21 June
\end{tabular}

Table 7: Results of the qualitative suitability evaluation of different land series for wheat under study, using Multicriteria evalution and GIS method

\begin{tabular}{lccc}
\hline Land units & Area & Percentage & Land class \\
\hline 1.1 & 868.32 & 16.08 & $\mathrm{~S} 3$ \\
1.2 & 316.44 & 5.86 & $\mathrm{~S} 3$ \\
1.3 & 507.60 & 9.40 & $\mathrm{~N} 1$ \\
2.1 & 986.04 & 18.26 & $\mathrm{~N} 2$ \\
2.2 & 457.38 & 8.47 & $\mathrm{~N} 2$ \\
2.3 & 369.90 & 6.85 & $\mathrm{~N} 2$ \\
3.1 & 844.02 & 15.63 & $\mathrm{~N} 2$ \\
3.2 & 738.18 & 13.67 & $\mathrm{~N} 2$ \\
3.3 & 312.12 & 5.78 & $\mathrm{~N} 2$ \\
\hline
\end{tabular}

corrigible non-suitable $\left(\mathrm{N}_{1}\right)$ and six units had non-suitability $\left(\mathrm{N}_{2}\right)$ for wheat cultivation. The results of climatic suitability evaluation showed that the climatic characteristics of the region according to that given by Sys et al. (1991) and climatic and growth data are suitable (without regarding o rainfall) for wheat plantation.

\section{DISCUSSION}

The results showed that from total units, $21.94 \%$ were under marginally suitable (S3) for wheat crop. This 


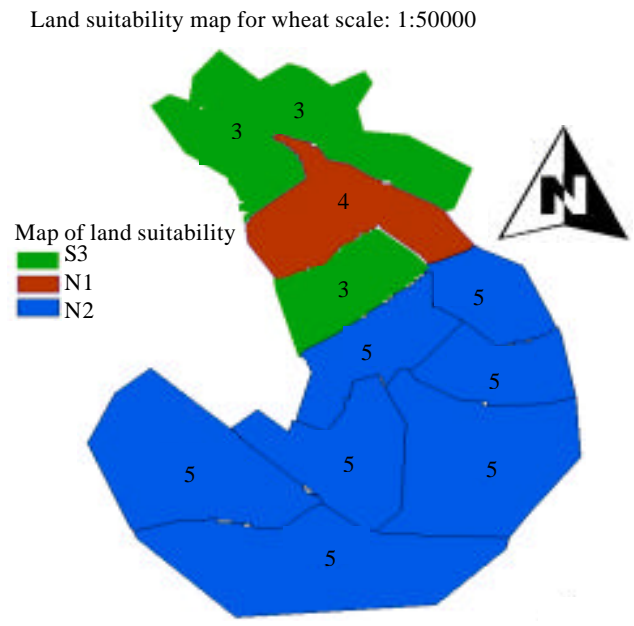

Fig. 3: Map of land suitability units for wheat in Damghan plain

suitability of units, Northern is because of long distance from desert and had soil, Exchangeable Sodium Percentage (ESP) and salinity lower than Southern units.

The results showed that $9.40 \%$ of study areas were not suitable (N1) and $68.66 \%$ severe limitations and unchangeable (N2) that this can be because of close to salt desert and lack of irrigation suitable water, soil salinity and poor soil fertility. Generally, not suitable areas (N) were located south of Damghan plain. The results showed that most suitable areas (S3) were found mostly in the soil mapping unit 1.1,2.1 (Fig. 3).

\section{CONCLUSION}

In this study, we applied Remote Sensing (RS) and GIS techniques to identify suitable areas for wheat crop. The proposed procedure for land suitability assessment and mapping can by utilizing analytical capability of modern GIS, make use of the limited available data for the assessment of the suitability of land for a certain land utilization type. By utilizing available data, it reduces the need of field and laboratory researches thus, reducing costs of evaluation. This investigation is a biophysical evaluation that provides information at a local level that could be used by farmers to select their cropping pattern. In this study, the most serious problems influencing yield and quality of wheat are Exchange Sodium Percent (ESP) and salinity (EC) and Northern units of Damghan plain have more suitability for wheat production. Therefore, based on obtained results, cultivation of wheat can be recommend in Northern areas.

\section{REFERENCES}

Dragan, M., E. Feoli, M. Fernetti and W. Zerihun, 2003. Application of a Spatial Decision Support System (SDSS) to reduce soil erosion in Northern Ethiopia. Environ. Modell. Software, 18: 861-868.

Eastman, J.R. and C. Labs, 1999. Idrisi32: Guide to GIS and Image Processing. Clark Labs, Clark University, Worcester, Massachusetts.

FAO, 1976. A framework for land evaluation. Food and Agriculture Organization of the United Nations, Soil Bulletin No. 32. Rome. http://www.fao.org/docrep/x $5310 \mathrm{e} / \mathrm{x} 5310 \mathrm{e} 00 . \mathrm{htm}$.

FAO, 1985. Guidelines: Land evaluation for irrigated agriculture. FAO Soils Bulletin, No. 55, FAO, Rome. http://www.fao.org/docrep/x5648e/x5648e00.htm.

Franzen, D.W., T. Nanna and W.A. Norvell, 2006. A survey of soil attributes in North Dakota by landscape position. Agron. J., 98: 1015-1022.

Ghaffari, A., H.F. Cook and H.C. Lee, 2000. Integrating climate, soil and crop information: A land suitability study using GIS. Proceedings of the 4th International Conference on Integrating GIS and Environmental Modeling (GIS/EM4): Problems, Prospects and Research Needs, Sept. 2-8, Banff, Alberta, Canada, pp: 1-14.

Malczewski, J., 1999. GIS and Multi-Criteria Decision Analysis. 1st Edn., John Wiley, Toronto, ISBN: 0471329444.

Pease, J.R., R.E. Coughlin and Estados Unidos. Natural Resources Conservation Service, 1996. Land Evaluation and Site Assessment: A Guidebook for Rating Agricultural Lands. Soil and Water Conservation Society, Ankeny, Iowa, pp: 240.

Pereira, J.M.C. and L. Duckstein, 1993. A multiple criteria decision-making approach to GIS-based land suitability evaluation. Int. J. Geogr. Inform. Sci., 7: 407-424.

Sys, C., E. van Ranst and J. Debaveye, 1991. Land Evaluation. Part 1: Principles in Land Evaluation and Crop Production Calculations. General Administration for Development Cooperation, Brussels, Belgium.

Sys, C., E. van Ranst, J. Debaveye and F. Beernaert, 1993. Land Evaluation. Part III. Crop Requirements. General Administration for Development Cooperation, Ghent, Belgium.

Van Lanen, H.A.J., M.J.D.H.T. Broeke, J. Bouma and W.J.M. de Groot, 1992. A mixed qualitative/ quantitative physical land evaluation methodology. Geoderma, 55: 37-54. 